\title{
Proposing a Syllabus Design for Oral Classes on Teachers' and Students' Perceptions of Modified Output
}

\author{
Inst. Akın Gürbüz ${ }^{1}$, Filiz Yalçin Tilfarlioğlü,** \\ ${ }^{1}$ English Language Department, Gaziantep University, Gaziantep, 27310, Turkey \\ ${ }^{2}$ School of Foreign Languages, Gaziantep University, Gaziantep, 27310, Turkey
}

Copyright $\mathrm{O} 2017$ by authors, all rights reserved. Authors agree that this article remains permanently open access under the terms of the Creative Commons Attribution License 4.0 International License

\begin{abstract}
Error treatment has long been studied in ELT, and the attitude of the learners and teachers towards correction might be acknowledged as the main focus in most cases. Breen et al.[1] put forward that negotiation is inevitable in modification; hence, the primary concern of this study is to explore teachers' and students' perceptions of modification in oral classes and present a communicative syllabus design based on the analysis of the needs. The participant instructors (48) and students (280) were addressed questionnaires to conceive their perception of corrective feedback in their oral classes. Both the questionnaires consisted of six sections, namely (1) necessity of error correction, (2) frequency of error treatment, (3) timing of modification, (4) types of errors need to be treated, (5) methods of correction and (6) delivering agents of corrective feedback. In terms of data collection, a variety of techniques such as questionnaires, audio recordings, and a semi-structured interview have been conducted. In this sense, collected data was analysed both quantitatively and qualitatively.
\end{abstract}

Keywords Modification, Modified-output, Oral Skills, Corrective-feedback, Syllabus-design

\section{Introduction}

Error treatment is not a new realm of study in ELT, but when it comes to correcting the learner's errors, hundreds of ways might emerge according to what the philosophy of the teacher is, what his or her attitude towards correction is, what method of teaching is being used, and a host of other factors which could play major parts in the game of correction. What has been in most cases in such studies is negligence of the attitudes of the learners and teachers towards correction. Following what Breen [1], Candlin [2], White [3] and Nunan [4] put forward by claiming that negotiation is inevitable and being inspired by a research done in this area by Fukuda [5], we decided to carry this research out to arrive at what learners' and teachers' reactions to the treatment of errors in oral classes are, and propose a syllabus design based on their attitudes.

Over the last decades, the interest in researching corrective feedback in second language acquisition has increased and various definitions have been offered since then. The terms negative evidence and corrective feedback have been used interchangeably by some researchers. Schachter [6], however, points out that the former is used mainly in the field of language acquisition whereas the latter is preferred in language teaching. Long [7] views feedback not just as negative evidence, but also positive. Positive evidence is when we provide the learners with models of what is grammatical and acceptable in the target language; and negative evidence is when we provide the learners with direct or indirect information of what is unacceptable. Lightbown and Spada [8] define corrective feedback as any indication to the learners that their use of the target language is incorrect. Although many studies have investigated teachers' preferences for and the effectiveness of corrective feedback in second language acquisition (e.g. Carpenter et al. [9]; Lyster [10]; Lyster \& Panova [11]; Lyster \& Ranta [12]), relatively few studies have investigated the possible differences between teachers' and students' preferences for error correction (e.g., Ancker [13]; Fukuda [5]; Yoshida [14]).

The indication to a learner that his use of the target language is incorrect falls into two categories; explicit or implicit, depending on the way the errors are corrected. Explicit feedback, as Kim and Mathes [15] stated in their article, refers to the explicit terms of the correct form, including specific grammatical information that students can refer to when an answer is incorrect, whereas implicit feedback such as elicitation, repetition, clarification requests, recasts and metalinguistic feedback (Lochtman [16]), allows learners to notice the error and correct it with the help of the teacher. Dekeyser [17], Lyster and Ranta [12], and Nassaji and Swain[18] investigated the effectiveness of corrective feedback; Havranek [19] aimed to identify the factors that may promote or oppose learning 
through corrective feedback; Kim and Mathes [15] conducted a study to see whether explicit and implicit feedback benefits learners more, and explored the range, and types of corrective feedback.

This study examines teachers' and students' perception of error correction in their oral classes, compares the differences, and suggests effective ways of treating students' spoken errors in EFL settings through a proposed syllabus design for oral communicative classes. The following questions are central to this article:

- Are there any significant differences between teachers' and students' perceptions of error correction practices?

- What are the sources of unmodified errors? (lack of knowledge, emotional, ignorance, etc.)

- What kind of a syllabus design can be proposed based on student and teacher attitudes towards modified output?

\section{Research Design}

In this study, a descriptive analysis was carried out to describe 280 students' and 48 teachers' attitude towards modified output and it aimed to propose a syllabus design for oral communicative classes. The data was collected through measurable instruments: Modified Output Questionnaire for Students- MOQ-S and Modified Output Questionnaire for Teachers MOQ-T adapted from Fukuda [5]. The questionnaires were previously used by Fukuda [5] and Park [20]. Both questionnaires were culturally adapted and one of the items regarding interrupting students' speech was excluded for humanistic reasons.

In addition to the questionnaires, interpretable instruments as a semi-structured interview with students and audiotaped classes of oral communicative skills have also been used in order to analyze collected data quantitatively and qualitatively. The questions for interview were adapted from modified output questionnaire for students.

Another tool used to collect data for this study was audio-taped recordings of oral communicative skill classes. In order to reflect types of modification were being used; what the student reactions were and improve the understanding of corrective feedback in teaching process eight lessons from each proficiency levels were recorded.

\section{Results and Discussions}

The questionnaires for students and teachers have six parts: oral communicative classes as (1) necessity of corrective feedback, (2) frequency of error correction, (3) timing of error correction, (4) types of errors treated, (5) methods of correction, and (6) agents of correction.

\subsection{Necessity of Error Correction}

In the first section of the questionnaire, students were asked to respond to statement, 'I want to receive corrective feedback'. Teachers were asked to respond to the statement, 'Students' spoken errors should be treated'. The findings indicate that both the students and teachers think students' spoken errors should be corrected, but the students believe in the necessity of corrective feedback to a much greater extent.

Researchers have investigated teachers' and students' perceptions of error correction and found mismatches between them. For example, Schulz's [21][22] studies revealed that students' attitudes toward grammar instruction and error correction were more favorable than their teachers' attitudes; that is, learners want more error correction. Similarly, Park [20] claimed that students wanted their errors to be treated more than teachers thought and when their instructional expectations are not met, their motivation can negatively be affected, and they may question the credibility of the teacher.

\subsection{Frequency of Error Correction}

The second part in the questionnaire asked students about the frequency of error treatment and expected to respond on a 5-point scale. Almost $25 \%$ of the students thought that their spoken errors should be 'always' corrected; whereas only about six percent of the teachers claimed that they always corrected students' errors. Almost the same cumulative percentage of the students and teachers agreed that students' spoken errors should 'always' and 'usually' be corrected, $56 \%$ and $52 \%$ respectively. There were $6.10 \%$ of the students who thought that their errors should 'never' be corrected while no teachers thought so. These findings indicate that there was a significant difference between the teachers and students in terms of frequency of error treatment.

\subsection{Timing of Error Correction}

Of the three choices, 'After the students finish speaking' received the highest mean from both the teachers and the students. On the other hand, 'At the end of the class' received the lowest mean from both groups. Furthermore, there was almost no difference between teachers' and students' mean for 'After the activity' responses. The results indicated that, both teachers and students were in favor of the immediate clarification without interrupting fluency of the speech and suspending till the end of the class. As Allwright and Bailey [23] argue, immediate error correction decreases students' motivation to speak and obstructs the flow of communication; however, in a similar way, long delayed or postponed feedback is not so effective either. 


\subsection{Types of Errors}

Almost all of the teachers responded that students' serious spoken errors should 'always or usually' be treated, whereas $72 \%$ of the students wanted their serious spoken errors to be 'always or usually' treated, and $9 \%$ of the students wanted their serious spoken errors to be treated sometimes. On the other hand, teachers' responses for less serious and infrequent were remarkably low compared to the students' demand for error correction even for those types which suggest students be keener in the sense of error treatment. Overall, the findings indicated that the students desired more error correction regardless of the types of errors.

\subsection{Methods of Corrective Feedback}

The fifth category asked the teachers and students about their preferences for types of corrective feedback. The category consisted of eight methods of corrective feedback: clarification request, repetition, implicit feedback, explicit feedback, elicitation, metalinguistic feedback, recasts, and no corrective feedback. Repetition and elicitation were the most favored methods of corrective feedback among the students, and an almost equal percentage of the students rated the methods as 'very effective or effective'. The findings indicated that the students wanted their teachers' repetition and elicitation feedback on their target-like utterances, and, they also wanted to have an opportunity to come up with these target-like language forms by themselves rather than entirely depending on their teachers' help.

\subsection{Delivering Agents of Error Correction}

The last group of questions asked the students who should correct their errors. The results illustrated that students regarded teachers as the most appropriate agent to correct student errors while teachers regarded student themselves as the most appropriate. The findings indicated that mean scores for peer-correction was the lowest among the three choices; that is, both the teachers and students did not strongly believe in the effectiveness of error correction delivered by classmates. Ever since a statistically significant difference was found between the two groups, teachers valued self-correction much more than students did. As Park [20] suggested, students may expect their teachers to have superior knowledge to offer corrective feedback.

\subsection{Correlations: of Teachers' and Students' Perceptions}

Means, standard deviations, and ranges between teachers' and students' perception of corrective feedback was analyzed in terms of six sections in the questionnaires. The results indicated that there was a significant difference between teachers' and students' perception of corrective feedback in general. The most significant divergence between the two groups could be seen in the necessity of the correction. The mean score of the students were higher than teachers' in general, except for the methods and delivering agents of corrective feedback. The results suggested that students were typically more demanding of error treatment and the teachers were well aware of the importance of it.

\subsection{Observations Outside-classroom}

The questionnaire (MOQ-S) results indicated that over 66\% of the students agreed or strongly agreed their errors to be treated in oral communicative classes. Additionally, a semi-structured interview was conducted with 30 students in groups of five. According to the interview held with students, it was well confirmed that no students in each group disagreed with necessity of error correction. Almost all of the students in each group wanted their errors to be corrected. In other words, very most of the students in all groups had strong opinions about the importance of error correction.

Furthermore, the evaluation of the interview indicated that the majority of the students were conscious of their spoken errors, so they wanted their errors to be corrected by their teachers most of the time rather than their classmates or the error left the student himself to be treated. The students claimed that the teacher was the source of information and his treatment of the error was not only a correction but also a kind of guidance for them. Furthermore, they said that the classmates were not reliable sources of correction as they might misinterpret the error treatment. In addition, majority of the students added that they felt uncomfortable and anxious to when they were corrected by classmates.

\subsection{In-class Observations}

Oral communicative classes were recorded for eight hours and the rates of in-class feedback occurrences in terms of corrective feedback methods, timing, delivering agents, and error types were presented on a table (see table 1). According to the results from in-class observations, implicit feedback was the most frequent corrective feedback type (58\%). Of all the implicit feedback implemented, $35 \%$ was given by the teacher, $15 \%$ by the classmates and $8 \%$ by the student himself.

Following the implicit feedback, other favorable feedback types were clarification request $(16 \%)$, explicit feedback $(10 \%)$, metalinguistic feedback $(6 \%)$, elicitation and recasts (4\%), repetition (2\%). There were no occurrences of 'no feedback' implementation in the classes. 
Table 1. Checklist for $\mathrm{CF}$ treatments in oral classes

\begin{tabular}{|c|c|c|c|c|c|c|c|c|c|c|}
\hline & Corrective Feedback Methods & Clarification Request & Repetition & $\begin{array}{c}\text { Implicit } \\
\text { Feedback }\end{array}$ & $\begin{array}{c}\text { Explicit } \\
\text { Feedback }\end{array}$ & Elicitation & $\begin{array}{c}\text { No } \\
\text { Feedback }\end{array}$ & $\begin{array}{l}\text { Metalinguistic } \\
\text { Feedback }\end{array}$ & Recasts & Total \\
\hline \multirow{3}{*}{ Timing } & After students finish speaking & 10 & 2 & 50 & 8 & 4 & - & - & - & 74 \\
\hline & After the activity & 4 & - & 4 & 2 & - & - & 5 & 4 & 19 \\
\hline & At the end of the class & 2 & - & 4 & - & - & - & 1 & - & 7 \\
\hline \multirow{3}{*}{$\begin{array}{c}\text { Delivering } \\
\text { Agents }\end{array}$} & Classmates & 2 & 1 & 10 & 2 & - & - & 2 & - & 17 \\
\hline & Teacher & 12 & 1 & 40 & 8 & - & - & 4 & 4 & 69 \\
\hline & Student himself & 2 & - & 8 & - & 4 & - & - & - & 14 \\
\hline \multirow{6}{*}{$\begin{array}{l}\text { Error } \\
\text { Types }\end{array}$} & Serious & 16 & - & 32 & 4 & - & - & 4 & - & 56 \\
\hline & Less serious & - & 1 & 3 & - & 1 & - & - & 2 & 7 \\
\hline & Frequent & - & - & 18 & 6 & 2 & - & 2 & - & 28 \\
\hline & Infrequent & - & 1 & 3 & - & - & - & - & 2 & 6 \\
\hline & Individual & - & - & 2 & - & 1 & - & - & - & 3 \\
\hline & - TOTAL & 16 & 2 & 58 & 10 & 4 & - & 6 & 4 & \\
\hline
\end{tabular}

In terms of timing of the correction, it was observed that $74 \%$ of feedback was conducted after students finish talking and $19 \%$ was conducted after the activity and only $7 \%$ was left to the end of the class. The most preferred time of correction was 'immediately after students finish talking'. In terms of delivering agents of corrective feedback, the results further indicated that $70 \%$ of the correction was delivered by the teacher, $18 \%$ by the classmates, while only $12 \%$ was conducted by the students themselves. Finally, types of errors were taken into account and similar to the results obtained from teacher and student questionnaires, serious and frequent student errors were observed to be the most common treated ones $(84 \%)$. To sum up, it was observed that implicit feedback was the most favored method of correction; after students finish talking was the most preferred timing for treatment; teacher was the most preferred agent of error correction; and serious errors were the most common errors modified.

\section{Conclusion}

The findings showed that both the teachers and students agreed student errors be treated, but students wanted more correction than their teachers assumed. Another similarity between the teachers and students was found regarding the timing of error correction. Similar to the teachers, students believed that error treatment after students finish speaking was effective. While both the teachers and students believed that serious and frequent errors should be treated, the students wanted to receive more error treatment. The students wanted error treatment even on infrequent and individual errors relatively. Repetition, implicit feedback, and elicitation were the three most favored types of feedback among the teachers; whereas repetition, elicitation and interestingly, metalinguistic feedback were the most favored types of corrective feedback among the students. As Kim and Mathes [15] stated in their article, explicit feedback refers to the explicit terms of the correct form, including specific grammatical information that students can refer to when an answer is incorrect; however, implicit feedback such as elicitation, repetition, clarification requests, recasts and metalinguistic feedback (Lochtman [16]), allows learners to notice the error and correct it with the help of the teacher. On the other hand, teachers were the most popular source of feedback for both the teachers and students. A discrepancy was found between the teachers and students regarding the 'student himself' as the delivering agent of error treatment.

The findings further displayed that though the teachers and students had reasonably similar opinions about the necessity, frequency and timing of error correction, they significantly differ from each other in terms of the method, and delivering agents of error correction, as well as types of errors that need to be corrected. A comprehensive interpretation of the classroom interactions indicated that implicit feedback was the most favored method of correction; after students finish talking was the best timing for treatment; teacher was the most preferred agent of error corrector; and serious errors were the most common errors modified. Further, from the inquiry of the interviews with six groups of students, the present study revealed that the main causes of unmodified errors arise due to refraining from anxiety, feeling uncomfortable, and over-accuracy.

In deciding the type of feedback to provide, the extent of explicitness is one of the issues the teacher must consider. 
Some teachers are concerned that corrective feedback might interrupt the flow of communication. Thus, some researchers claim that recasting is a powerful tool in that it can provide opportunities for learners to become aware of the mismatch between output and input without interrupting communicative flow (e.g., Doughty [24]; Doughty \& Varela [25]; Long \& Robinson [26]). Doughty [24] suggests that recasting can be effective if it is targeted at only limited linguistic features and is provided with a clear signal. Lyster and Ranta [12] and Lightbown [27] maintain that explicit feedback can be provided without breaking the flow of communication if it is given in a short time and the class resumes the conversation. It is pointless to assert a type of feedback better over another, but teachers are expected to take linguistic and non-linguistic elements of each setting into consideration, such as complexity of target forms, influence or interference from learners' native languages, level of proficiency, motivation, ultimate target level, and so forth. For instance, Carroll and Swain [28] suggested explicit instruction combined with explicit metalinguistic feedback be beneficial for students to understand complicated rules. In addition, non-linguistic factors like age and motivation might account for different results from similar feedback as the studies of Lyster and Ranta [12] and Ellis et al. [29] revealed.

\section{The Proposed Syllabus Design}

This study aimed to propose a syllabus design in the light of what has come out of the collected data through various tools as questionnaires, interviews and recordings (see Figure 1). The syllabus is designed relying on information collected, research and actual practices in the related department. The comparison and analysis of the participant perceptions were considered to be the starting point in designing a syllabus model.

\subsection{The Model}

To implement an effective communicative course, a syllabus model depending on the analysis of modified output was proposed. The data collected through questionnaires, semi-structured interviews and in-class observations assisted the researcher to define the content and materials to generate interactions (namely student-teacher interaction, student-student interaction, and group interaction) which would be followed by different methods of correction (namely self-correction, peer-correction, and teacher correction).

The suggested model was mainly based on process-oriented syllabus design. Therefore it was adapted from various syllabus types such as the communicative syllabus model of Munby [30], the Skill-Centered syllabus model (Hutchinson and Waters [31]) and Candlin's [32] syllabus model.

As can be seen in Figure 1, the model starts with the statement of the general goals. The general goals will explain the need for organizing the communicative classes within preparatory program. The major component of the model constitutes a needs analysis process which tries to identify communicative skill needs by distributing questionnaires to a number of students and teachers, conducting interviews with students and recordings of speaking classes. Identification of needs enables the researcher to define specific goals and objectives. Specific goals and objectives of the program should be based upon the results of corrective feedback needs analysis. Selection of content, activities and materials follow statements of specific goals and objectives.

When selecting the content and the activities, the students' needs, expectations, preferences and individual characteristics need to be considered as well as the teachers. The content and activities chosen should generate teacher-student interaction, student-student interaction and group interaction. The modification of the errors in the shed of teacher and student expectations is to be performed through these interactions. Therefore, the interaction types will play an important role on three main points emphasized in the study: the method of correction (implicit or explicit), the agent of correction (teacher, classmate or student himself), the timing of correction (after student finish talking, after the activity or after the class).

In that sense, the modifications in classroom practices should definitely be varied and encouraged. The instruction phase includes methodology, teaching and learning strategies to reach the goals of the program. The suggested syllabus model is expected to contribute to the development of the communicative course as it provides guidelines for the course designers so that the consistent decisions can be made to increase the effectiveness of the program. 


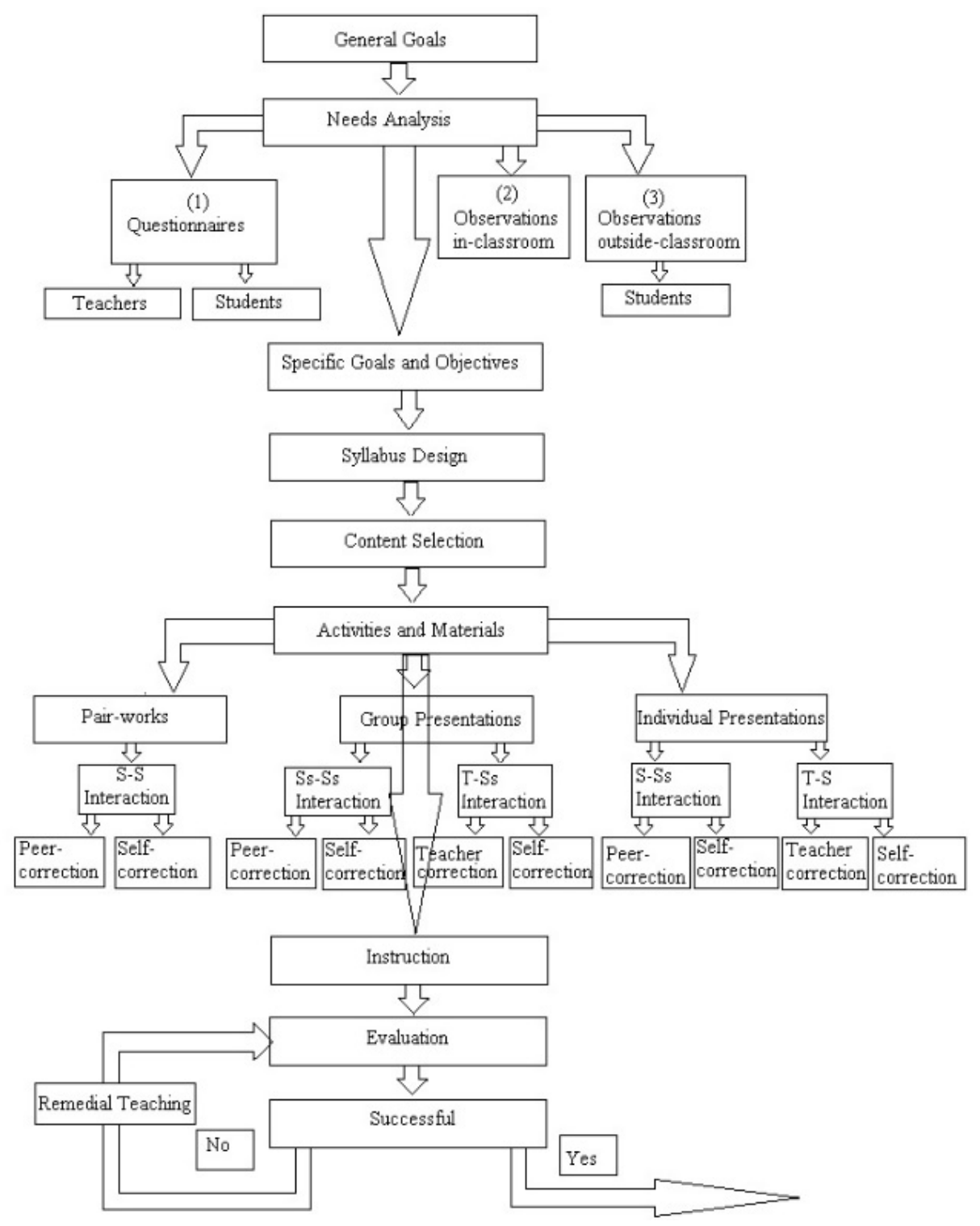

Figure 1. Process-oriented syllabus model

\section{Pedagogical Implications}

According to the noticing hypothesis theory (Schmidt [33]), in order for something to be learned, it has to be noticed first, however, noticing on its own does not result in acquisition. Learners have to consciously pay attention to or notice the input to transform it into intake for L2 learning. In this way, Modified Output triggers learners to recognize the gaps between the target norms and their own interlanguage which leads to grammatical restructuring. While second language students make errors as part of the learning process, drawing attention to these errors is an important aspect to their language development.

Corrective feedback provides learners the information that helps them notice their errors. Ferris [34] suggests that students 'need distinct and additional intervention from their teachers to make up their deficits and develop strategies for finding, correcting, and avoiding errors. While the value of written corrective feedback has been centered on its effectiveness in helping learners' linguistic improvement, it is also important to highlight that learner's favor correction and expect it. Thus, in perceiving different types of feedback and enhancing their benefits for language learners, noticing and awareness is vital. (Rezaei et al. [35]).

As Burt [36] pointed out, the correction of one global error clarifies the intended message more than the correction of several local errors. Burt further argued that high-frequency errors should be the first errors teachers should correct. The results of the current study supported the claims represented by Burt and indicated that that most frequent errors are those primarily favored both by teachers and students to be treated as well as serious errors that may cause misunderstanding. Lyster and Ranta's [12] findings revealed that since student-initiated repairs in error correction help them consolidate their current knowledge of the target language and lead the learners to revise their 
hypotheses about the target language, they are important in L2 learning. Accordingly, the findings of the teacher questionnaire (MOQ-T) suggested that a great proportion of the teachers strongly agree or agree that the student himself should be the delivering agent of the error treatment.

In the case of oral corrective feedback, two key distinctions figure: (1) explicit vs. implicit CF (e.g., Carrol \& Swain [28]; Aljaafreh \& Lantolf [37]) and (2) input-providing vs. output-prompting CF (Lyster [38]; Ellis [39]). Throughout the analysis of the present study, it has been concluded that while implicit feedback was the most implemented type of corrective feedback by the teachers in oral communicative classes, explicit feedback received the highest score by the students. Furthermore, in a more traditional narrative survey of the research, Ellis et al.[40]concluded that (1) both types of corrective feedback, implicit and explicit, assist acquisition and (2) explicit feedback is generally more effective than implicit.

The results of the present study were further used in preparation of a communicative syllable design for oral classes. The long-term result of this practical product is that students may become more active in their own learning when the treatments of different error types are conducted in the classroom. As a result, students may no longer insist on teacher oriented error treatment in classroom, but also favor self-initiated error correction. For this, the classroom activities can be managed to provide students with the tools that they need to succeed in other environments and thus construct self-correction. Moreover, students can be provided with feedback and positively motivated on a regular basis to make self-initiated treatment available to them.

\section{REFERENCES}

[1] Breen, M.P. (1984) 'Process Syllabuses for the Language Classroom' in Brumfit, CJ. (ed.) General English Syllabus Design Pergamon Press Ltd. and The British Council.

[2] Candlin, C. N. (1984). Syllabus design as a critical process. In C. J. Brumfit (Ed.), General English syllabus design (pp. 29-46). Oxford: Pergamon Press.

[3] White, R. V. (1988). The ELT curriculum: design, innovation and management. Oxford: Basil Blackwell.

[4] Nunan, D. (1999). Second language teaching and learning. Boston: Heinle \& Heinle Publishers.

[5] Fukuda, Y. (2004). Treatment of spoken errors in Japanese high school oral communication classes. Master's thesis, California State University, San Francisco.

[6] Schachter, J. (1991). Corrective feedback in historical perspective. Second Language Research, 7, 89-102.

[7] Long, M.H. (1996). The role of linguistic environment in second language acquisition. In W. C. Ritchie \& B. K. Bahtia (Eds.), Handbook of second language acquisition (pp.
413-468). New York: Academic Press.

[8] Lightbown, P.M., \& Spada, N. (1999). How languages are learned: Revised edition. Oxford: Oxford University Press.

[9] Carpenter, H., Jeon, K., Macgregor, D., \& Mackey, A. (2006). Learners' interpretation of recasts. Studies in Second Language Acquisition, 28, 209-236.

[10] Lyster, R. (1998). Recasts, repetition, and ambiguity in L2 classroom discourse. Studies in Second Language Acquisition, $20,51-81$

[11] Lyster, R., \& Panova, I. (2002). Patterns of corrective feedback and uptake in an adult ESL classroom. TESOL Quarterly, 36(4), 573-595.

[12] Lyster, R. \& Ranta, L. (1997). Corrective feedback and learner uptake: Negotiation of form in communicative classrooms. Studies in Second Language Acquisition, 19, 37-66.

[13] Ancker, W. (2000). Errors and corrective feedback: Updated theory and classroom practice. English Teaching Forum, 38(4), 20-24.

[14] Yoshida, R. (2008). Teachers' choice and learners' preference of corrective feedback types. Language Awareness, 17(1), 78-93.

[15] Kim, H. R., \& Mathes, G. (2001). Explicit vs. implicit corrective feedback. The Korea TESOL Journal, 4(1), 57-72.

[16] Lochtman, K. (2002). Oral corrective feedback in the foreign language classroom: How it affects interaction in analytic foreign language teaching. International Journal of Educational Research, 37(3), 271-283.

[17] Dekeyser, R. M. (1993). The effect of error correction on L2 grammar knowledge and oral proficiency. The Modern Language Journal, 77(4), 501-514.

[18] Nassaji,H. \& Swain, M. (2000). A Vygotskian perspective on corrective feedback in L2: The effect of random versus negotiated help on the learning of English articles. Language Awareness, 9(1), 34-51.

[19] Havranek, G. (1999). The effectiveness of corrective feedback: Preliminary results of an emprical study. Acquisition et Interaction en Langue Etrangere, 2, 189-206.

[20] Park, H. S. (2010). Teachers' and Learners' Preferences for Error Correction. Unpublished Dissertation.

[21] Schulz, R. A. (2001). Cultural differences in student and teacher perceptions concerning the role of grammar instruction and corrective feedback: USA-Colombia. The Modern Language Journal, 85, 244-258.

[22] Schulz, R. A. (1996). Focus on form in the foreign language classroom: Students' and teachers' views on error correction and the role of grammar. Foreign Language Annals, 29(3), 343-364

[23] Allwright, D., \& Bailey, K.M. (1991). Focus on the language classroom: An introduction to classroom research for language teachers. Cambridge: Cambridge University Press.

[24] Doughty, C. (1999). The cognitive underpinnings of focus on form. University of Hawai' $i$ Working Papers in ESL, 18, 1-69.

[25] Doughty, C., \& Varela, E. (1998). Communicative focus on form. In C. Doughty \& J. Williams (Eds.). 
[26] Long, M. H., \& Robinson, P. (1998). Focus on form: Theory, research, and practice.

[27] Lightbown, P.M. (1998). The importance of timing in focus on form. In C. Doughty \& J. Williams (Eds.), Focus on form in classroom second language acquisition (pp. 177-196). Cambridge: Cambridge University Press.

[28] Carroll, S., \& Swain, M. (1993). Explicit and implicit negative feedback: An empirical study of the learning of linguistic generalizations. Studies in Second Language Acquisition, 15, 357-366.

[29] Ellis, R., Basturkmen, H., \& Loewen, S. (2001). Learner uptake in communicative ESL lessons. Language Learning, 51, 281-318.

[30] Munby, J. (1978). Communicative Syllabus Design. London: Cambridge University Press.

[31] Hutchinson, T., \& Waters, A. (1996). English for Specific Purposes: A Learning-centred Approach. Cambridge: Cambridge University Press.

[32] Candlin, C. N., Kirkwood, J. M., \& Moore, H. M. (1978). Study skills in English: Theoretical issues and practical problems. In R. Mackay, \& A. Mountford (Eds.), English for Specific Purposes. London: Longman Group Limited.

[33] Schmidt, R. (1990). The Role of Consciousness in Second
Language Learning. Applied Linguistics, 11, 129-158.

[34] Ferris, D. (2002). Treatment of error in second language student writing. Ann Arbor: University of Michigan Press.

[35] Rezaei, S., Mozaffari, F., \& Hatef, A. (2011). Corrective Feedback in SLA: Classroom Practice and Future Directions. International Journal of English Linguistics, 21-29.

[36] Burt, H.D. (1975). Error analysis in the adult EFL classroom. TESOL Quarterly, 9(1), 53-63.

[37] Aljaafreh, A. \& J. Lantolf. (1994). Negative feedback as regulation and second language learning in the Zone of Proximal Development. The Modern Language Journal, 78, 465-483.

[38] Lyster, R. (2004). Differential effects of prompts and recasts in form-focused instruction. Studies in Second Language Acquisition, 26, 399-432.

[39] Ellis, R. (2006). Researching the effects of form-focused instruction on L2 acquisition. In K. Bardovi-Harlig \& Z. Dornyei (Eds.), Themes in SLA Research. AILA, 19, 18-41. Amsterdam: John Benjamins.

[40] Ellis, R., Loewen, S., \& Erlam, R. (2005). Implicit and explicit corrective feedback and the acquisition of L2 grammar. Studies in Second Language Acquisition, 28, 339-368. 